\title{
Genetic diversity of the xerothermic weevils Polydrusus inustus and Centricnemus leucogrammus (Coleoptera: Curculionidae) in central Europe
}

\author{
ŁuKasz KAJTOCH ${ }^{1}$, Dorota LACHOWSKA-CIERLIK ${ }^{2}$ and MIECZYSŁaw MAZUR ${ }^{3}$ \\ ${ }^{1}$ Institute of Systematics and Evolution of Animals, Polish Academy of Science, Sławkowska 17 St., Krakow, Poland, \\ e-mail: kajtoch@isez.pan.krakow.pl \\ ${ }^{2}$ Institute of Zoology, Department of Entomology, Jagiellonian University, Ingardena 6 St., Krakow, Poland \\ ${ }^{3}$ Institute of Biology, Pedagogical Academy, Podbrzezie 3, Krakow, Poland
}

Key words. Curculionidae, weevils, mtDNA, phylogeography, xerothermic habitats

\begin{abstract}
Phylogeography, genetic diversity, and demography of central European populations of two flightless xerothermic weevils, Polydrusus inustus and Centricnemus leucogrammus, were studied based on the polymorphism of three mtDNA genes (COII, CytB, and ND1). Results indicate that these xerothermic beetles may have different origins. P. inustus is a recent migrant as the parthenogenetic form has a low level of genetic diversity and lacks a geographic population structure. This is probably a result of a recent (before the end of last glaciation) expansion and/or present dispersal mediated by humans. On the other hand, C. leucogrammus appears to be a relic species as the populations of this species are much more genetically diverse (six distinct clades) and some of the populations are allopatric and others sympatric. They probably diverged and expanded during the last few glaciations. Genetic discontinuities were detected among localities that are now separated by gaps in the distribution. Boundaries (mountains or farmland) separate the populations into three groups: (1) Moravia and Slovakia, (2) the lower Vistula Valley in northern Poland and (3) south-eastern Poland together with western Ukraine. Evidence for recent gene flow was found only among populations from south-eastern Poland and western Ukraine, and between these two groups. One population from northern Poland was surprisingly related to populations in southern Poland, which may be due to extinction of intermediate populations.
\end{abstract}

\section{INTRODUCTION}

The present distribution of species in central Europe is a result of their glacial and postglacial history and the impact of anthropogenic transformations on environments. The origin of many species is reconstructed on the basis of paleontological, chorological, and genetic data. Most of the species studied occur in the temperate and boreal zones (Taberlet et al., 1998; Hewitt, 1999; Avise, 2000; Varga, 2003). In contrast, our knowledge of the history of species that inhabit dry environments on the continent (e.g. steppe), is based mainly on paleontological and pollen data (Kowalski et al., 1989; Tarasov et al., 2000). Steppe-tundra environments were common in Europe in areas between ice sheets in the north, and mountains or forest zones in the south (Nehring, 1890; Willis \& van Andel, 2004). After climate warming, these environments started to contract and move: tundra to the north and higher altitudes, steppe to south-eastern areas of Europe. At present, areas of potential natural steppe environment in Europe are limited to the Ukraine, Caspian area, and Pannonian Basin. Xerothermic habitats similar to steppe exist in many places in western and central Europe and the Balkans. These habitats consist mostly of small patches such as isolated turfs and thickets on steep slopes of hills and along river beds. The origin of these habitats is unclear. They have been considered as relicts of steppe-tundra environments. Alternatively, they may have resulted from the deforestation that has occurred over the last few thousand years. It is also pos- sible that some forest or grassland species may have adapted to these dry environments and colonized them. An intermediate hypothesis claims that some xerothermic habitats are natural relicts whereas others are of anthropogenic origin. Consequently, some species should be native to these habitats, persisting for long periods of time, while others should be new migrants. Unlike the changes in the distribution of temperate and boreal environments, steppe-like habitats were common during glaciations but contracted during warmer periods. Steppe and xerothermic habitats regressed in the Holocene. It is possible that present xerothermic habitats are "warmstage refuges" for species that formerly inhabited steppelike environments (Bhagwat \& Willis, 2008).

Among the most common xerothermic species are insects. Faunistic studies on xerothermic insects in central Europe are based mainly on the present distribution of grasshoppers (Orthoptera) and weevils (Curculionidae) (Liana, 1987; Mazur, 2001). The only examples of phylogeographic analyses of semi-steppe insects in Europe are on butterflies (Lepidoptera), which are highly mobile so might have survived glacial periods in more southern refugees and afterwards expanded their range northwards (Bereczki et al., 2005; Gratton et al., 2008). On the other hand, there is little knowledge on the history of flightless, xerothermic insects.

This paper presents the results of a study of the genetic diversity of central European populations of two species of weevils from the subfamily Entiminae, Polydrusus inustus Germar, 1824 and Centricnemus leucogrammus 
(Germar, 1824). P. inustus inhabits an area between the Ural and Caucasus Mts in the east, and south-eastern Poland and the eastern slopes of the Carpathians in the west (Korotyaev, 1996). This species does not live in the Pannonian Basin. Some isolated populations occur farther to the west and north in Poland (Mazur, 2001). Populations of this weevil over most of its range consist of parthenogenetic females and, at least in Poland, they are triploid (Lachowska et al., 2008). Bisexual populations are known only from Georgia and Turkey (Korotyaev, 1996). These weevils live mostly on Rosacea in xerothermic habitats but sometimes are also found in dry wastelands. The main range of $C$. leucogrammus stretches from central Asia to southern Poland. A disjunctive part of its range is situated in the Pannonian Basin and along the Danube valley. Isolated populations are also found farther to the north - in Pomerania in Poland (Mazur, 2001). This species is bisexual and diploid (Petryszak, 1977; Lachowska et al., 2006). It lives exclusively on plants in dry and warm xerothermic turfs and steppe. These two species are flightless and their ability to disperse over great distances limited, especially currently, because of the fragmentation of xerothermic habitats in central Europe. On the other hand, at least for P. inustus, it is postulated that human mediated dispersal is possible as this species might survive in, e.g. strawberry fields (Mazur, 2001). Low mobility allows their expansion routes and range contractions to be assessed over a longer perspective. They are also polyphagous, implying that their present range was not limited by the availability of food in the past.

The aim of this study was to describe the phylogeography, estimate genetic diversity and level of gene flow among central European populations of these two weevils, and calculate divergence and expansion times for these populations. Comparison of the results for the two species allowed us to infer the history of flightless xerothermic beetles (both bisexual and parthenogenetic) in the north of central Europe closest to the area covered by the ice-sheet during the Pleistocene.

\section{MATERIAL AND METHODS}

Both species were collected from most of their ranges in the north of the Carpathian Mountains. For C. leucogrammus, material was also collected from two localities in the south of the Carpathians (Table 1, Fig. 1a, b). Only parthenogenetic individuals of $P$. inustus were collected because bisexual populations are unknown in Europe other than those in the Caucasus Mountains. Adults of these beetles were collected on several expeditions in 2005-2008. Samples were first preserved in 99\% ethanol and then stored at $-22^{\circ} \mathrm{C}$. For DNA analyses, 5 individuals per population were taken, with the exception of the HAL population of $P$. inustus for which only 2 specimens were available. DNA was extracted from whole insect bodies using the DNeasy Tissue Kit (Qiagen, Hilden, Germany). Amplification of three fragments of mitochondrial DNA (mtDNA; total length of more than $1600 \mathrm{bp}$ ), including cytochrome oxidase II (COII), cytochrome b (CytB), and nicotinamide adenine dinucleotide dehydrogenase 1 (ND1) along with the tRNA ${ }^{\text {Leu }}$ gene, was performed using the following pairs of primers, respectively: TL2-J-3038 and TK-N-3782, CB-J-10933 and CB-
N-10920, N1-J-12533 and LR-N-12866 (Simon et al., 1994). The cycling profile for the PCR was: $95^{\circ} \mathrm{C}$ for $4 \mathrm{~min}, 35$ cycles of $95^{\circ} \mathrm{C}$ for $30 \mathrm{~s}, 50^{\circ} \mathrm{C}$ for $1 \mathrm{~min}, 72^{\circ} \mathrm{C}$ for $2 \mathrm{~min}$, and a final extension period of $72^{\circ} \mathrm{C}$ for $10 \mathrm{~min}$. After purification PCR fragments (QIAquick PCR Purification Kit, Qiagen) were sequenced using the BigDye Terminator v.3.1. Cycle Sequencing Kit (Applied Biosystems Inc., Foster City, USA) and an ABI 3100 Automated Capillary DNA Sequencer. All sequences were deposited in GenBank (accession numbers FJ442860-FJ442930, strain numbers correspond to combined haplotypes of COII-CytB-ND1 genes whose numbers are used in this paper). Sequences were checked and aligned using BioEdit v.7.0.5.2 (Hall, 1999) and ClustalX (Thompson et. al., 1997). No indels (i.e. insertions or deletions) or stop codons were observed. The three fragments of mtDNA genes obtained (COII, CytB, and ND1) were subjected to a partitionhomogenity test (Farris, 1995) using PAUP* 4.10b (Swofford, 2002), which showed that further analyses could be performed on combined sequences. Haplotypes were identified and standard genetic indices such as haplotype diversity $(h)$, nucleotide diversity $(\pi)$ and number of private haplotypes $(\mathrm{Np})$ for populations were computed using the program DnaSP 4.20.2 (Rozas et al., 2003).

\section{Phylogeny and phylogeography}

The Akaike information criterion in MODELTEST (Posada \& Crandall, 1998) was used to determine the best-fitting nucleotide substitution model. Parameters of 56 models of sequence evolution were estimated in PAUP* 4.10b (Swofford, 2002). The HKY+I model was chosen for P. inustus and the HKY $+\mathrm{I}+\mathrm{G}$ model for C. leucogrammus (Hasegawa et al., 1985). Unrooted haplotype trees were obtained for each species using Bayesian inference in MrBayes 3.1 (Huelsenbeck \& Ronquist, 2001; Ronquist \& Huelsenbeck, 2003). A distribution of posterior probabilities was produced by allowing four incrementally heated Markov chains (using default heating values) to proceed for $2 \times$ $10^{7}$ generations, with sampling occurring every $1 \times 10^{3}$ generations. The approximate number of generations needed to obtain convergence of the sampled trees was estimated graphically, and was 500 for both species. These samples were discarded (burn-in) from the analyses and the remaining samples were used to produce a $50 \%$ majority rule consensus tree. For estimation of divergence times between main clades, pairwise distances among them were calculated according to $t=\left(d_{x y}-\right.$ $0.5^{*}\left(d_{x}+d_{y}\right)^{*} \mu$, where $d_{x}$ and $d_{y}$ denote the average sequence diversity within, and $d_{x y}$ the sequence diversity among clades, respectively (Nei, 1987) and $\mu$ is the mutation rate. There is no data on divergence times or mutation rates for any xerothermic beetles because their chitin outer skeleton is not preserved in an alkaline environment. Therefore, the mutation rate was assumed to be $1.5-2.0 \%$ per million years as calculated for the mtDNA of other beetles (Juan et al., 1996; Farrell, 2001; Ribera et al., 2001; Caccone \& Sbordoni, 2001; Barraclough \& Vogler, 2002). In addition to Bayesian trees, haplotype networks were constructed using the statistical parsimony method (SP) (Templeton et al., 1992) and TCS 1.21 program (Clement et al., 2000). Based on these networks, nested clade phylogeographic analyses (NCPA) (Templeton, 1998, 2001; Emerson et al., 2001) were done using the program ANeCA (Panchal, 2007; Panchal \& Beaumont, 2007), which is composed of GEODIS 2.4 (Posada et al., 2000) and Templeton's inference key (Templeton, 2004). The utilization of NCPA for reconstructing events in the past history of populations was recently questioned (i.e. Knowles \& Maddison, 2002; Petit \& Grivet, 2002; Beaumont \& Panchal, 2008). However, it was also indicated that this method may be useful providing any inferences are interpreted in the 
TABLE 1. The localities and standard genetic indices ( $h$ - haplotype diversity; $\pi$ - nucleotide diversity; Np - number of private haplotypes) of the populations of P. inustus and C. leucogrammus studied.

\begin{tabular}{|c|c|c|c|c|c|}
\hline Symbol of population $^{a}$ & Geographic coordinates & $h \pm \mathrm{SD}$ & $\pi \pm \mathrm{SD}(\%)$ & $\mathrm{Np}$ & Haplotypes (number of specimens) \\
\hline \multicolumn{6}{|c|}{ Polydrusus inustus } \\
\hline KRA & 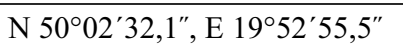 & $0.4 \pm 0.24$ & $0.024 \pm 0.01$ & 1 & $\mathrm{P} 1[4], \mathrm{P} 2[1]$ \\
\hline DAL & N $50^{\circ} 19^{\prime} 58,6^{\prime \prime}$, E $20^{\circ} 12^{\prime} 55,4^{\prime \prime}$ & $0 \pm 0$ & $0 \pm 0$ & 0 & P3 [5] \\
\hline $\mathrm{CHO}$ & N $50^{\circ} 22^{\prime} 30,5^{\prime \prime}$, E $20^{\circ} 42^{\prime} 43,9^{\prime \prime}$ & $0.7 \pm 0.22$ & $0.048 \pm 0.02$ & 1 & $\mathrm{P} 1$ [1], P3 [3] \\
\hline $\mathrm{BOC}$ & N $51^{\circ} 20^{\prime} 33,1^{\prime \prime}$, E $21^{\circ} 58^{\prime} 48,6^{\prime \prime}$ & $0.7 \pm 0.05$ & $0.071 \pm 0.03$ & 1 & P1 [3], P5 [1], P13 [1] \\
\hline GRO & N $50^{\circ} 48^{\prime} 01,6^{\prime \prime}$, E $23^{\circ} 57^{\prime} 12,7^{\prime \prime}$ & $0.6 \pm 0.18$ & $0.029 \pm 0.01$ & 1 & P1 [3], P6 [2] \\
\hline KOR & 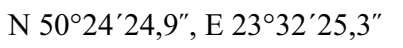 & $0 \pm 0$ & $0 \pm 0$ & 0 & P7 [5] \\
\hline MIE & $\mathrm{N} 52^{\circ} 19^{\prime} 21,3^{\prime \prime}$, E $23^{\circ} 02^{\prime} 12,2^{\prime \prime}$ & $0 \pm 0$ & $0 \pm 0$ & 0 & P7 [5] \\
\hline $\mathrm{ROZ}$ & 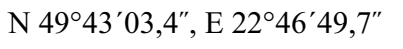 & $0.4 \pm 0.24$ & $0.048 \pm 0.03$ & 1 & P1 [4], P8 [1] \\
\hline JAR & N 495' $34,3^{\prime \prime}$, E $22^{\circ} 38^{\prime} 14,2^{\prime \prime}$ & $0 \pm 0$ & $0 \pm 0$ & 0 & P1 [5] \\
\hline SZC & N 495 $56^{\prime} 28,6^{\prime \prime}$, E $20^{\circ} 53^{\prime} 06,9^{\prime \prime}$ & $0.4 \pm 0.24$ & $0.024 \pm 0.01$ & 1 & $\mathrm{P} 1$ [4], P9 [1] \\
\hline BIS & N 495 $58^{\prime} 06,5^{\prime \prime}$, E $20^{\circ} 06^{\prime} 55,5^{\prime \prime}$ & $0 \pm 0$ & $0 \pm 0$ & 1 & P10 [1] \\
\hline KAL & N $51^{\circ} 59^{\prime} 14,4^{\prime \prime}$, E $21^{\circ} 13^{\prime} 59,3^{\prime \prime}$ & $0.6 \pm 0.18$ & $0.036 \pm 0.01$ & 1 & $\mathrm{P} 1$ [3], P11 [2] \\
\hline MOD & N 52॰25'59,9", E $20^{\circ} 41^{\prime} 25,7^{\prime \prime}$ & $0 \pm 0$ & $0 \pm 0$ & 1 & P12 [5] \\
\hline WLO & 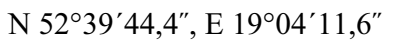 & $0 \pm 0$ & $0 \pm 0$ & 0 & $\mathrm{P} 7[5]$ \\
\hline GOG & N 50॰29'30, $8^{\prime \prime}$, E $18^{\circ} 02^{\prime} 59,5^{\prime \prime}$ & $0 \pm 0$ & $0 \pm 0$ & 0 & P7 [5] \\
\hline GLO & 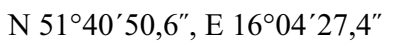 & $0 \pm 0$ & $0 \pm 0$ & 0 & $\mathrm{P} 7[5]$ \\
\hline SAN & N $50^{\circ} 41^{\prime} 26,0^{\prime \prime}$, E $21^{\circ} 48^{\prime} 40,5^{\prime \prime}$ & $0.4 \pm 0.24$ & $0.048 \pm 0.03$ & 0 & $\mathrm{P} 1$ [1], P13 [4] \\
\hline ZLO & N 493' $58,3^{\prime \prime}$, E $24^{\circ} 37^{\prime} 00,5^{\prime \prime}$ & $0.4 \pm 0.24$ & $0.024 \pm 0.01$ & 1 & P1 [4], P14 [1] \\
\hline HAL & N 483' $19,9^{\prime \prime}$, E $24^{\circ} 57^{\prime} 47,2^{\prime \prime}$ & $0 \pm 0$ & $0 \pm 0$ & 1 & P15 [2] \\
\hline \multicolumn{6}{|c|}{ Centricnemus leucogrammus } \\
\hline DAL & N $50^{\circ} 19^{\prime} 58,6^{\prime \prime}$, E $20^{\circ} 12^{\prime} 55,4^{\prime \prime}$ & $0.7 \pm 0.05$ & $0.049 \pm 0.02$ & 2 & $\mathrm{C} 1[3], \mathrm{C} 2[1], \mathrm{C} 3$ [1] \\
\hline $\mathrm{CHO}$ & N $50^{\circ} 22^{\prime} 30,5^{\prime \prime}$, E $20^{\circ} 42^{\prime} 43,9^{\prime \prime}$ & $0.8 \pm 0.16$ & $0.431 \pm 0.12$ & 1 & C4 [2], C5 [2], C6 [1] \\
\hline DOB & $\mathrm{N} 51^{\circ} 17^{\prime} 02,2^{\prime \prime}$, E $21^{\circ} 53^{\prime} 03,1^{\prime \prime}$ & $0.8 \pm 0.16$ & $0.431 \pm 0.12$ & 1 & $\mathrm{C} 4[2], \mathrm{C} 5[2], \mathrm{C} 7[1]$ \\
\hline GRO & N $50^{\circ} 48^{\prime} 01,6^{\prime \prime}$, E $23^{\circ} 57^{\prime} 12,7^{\prime \prime}$ & $0.4 \pm 0.24$ & $0.025 \pm 0.02$ & 2 & C8 [4], C9 [1] \\
\hline GRE & 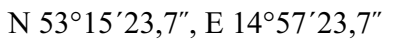 & $0.4 \pm 0.24$ & $0.025 \pm 0.02$ & 2 & $\mathrm{C} 10[4], \mathrm{C} 11[1]$ \\
\hline BRA & $\mathrm{N} 48^{\circ} 08^{\prime} 00,0^{\prime \prime}, \mathrm{E} 17^{\circ} 06^{\prime} 00,0^{\prime \prime}$ & $0.9 \pm 0.16$ & $0.160 \pm 0.05$ & 4 & $\mathrm{C} 12$ [2], C13 [1], C14 [1], C15 [1] \\
\hline NIE & 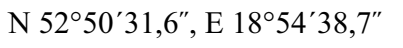 & $0.6 \pm 0.18$ & $0.074 \pm 0.02$ & 2 & $\mathrm{C} 16[3], \mathrm{C} 17[2]$ \\
\hline PLU & N 53ำ $15^{\prime} 55,8^{\prime \prime}$, E $18^{\circ} 24^{\prime} 06,5^{\prime \prime}$ & $0.7 \pm 0.22$ & $0.148 \pm 0.07$ & 3 & C18 [3], C19 [1], C20 [1] \\
\hline SAN & N $50^{\circ} 41^{\prime} 26,0^{\prime \prime}$, E $21^{\circ} 48^{\prime} 40,5^{\prime \prime}$ & $1.0 \pm 0.13$ & $0.148 \pm 0.04$ & 5 & C21 [1], C22 [1], C23 [1], C24 [1], C25 [1] \\
\hline ZLO & N 4939'58,3", E $24^{\circ} 37^{\prime} 00,5^{\prime \prime}$ & $0.7 \pm 0.13$ & $0.148 \pm 0.04$ & 3 & $\mathrm{C} 26[3], \mathrm{C} 27[1], \mathrm{C} 28[1]$ \\
\hline BRO & N 495' $27,7^{\prime \prime}$, E $25^{\circ} 02^{\prime} 01,6^{\prime \prime}$ & $1.0 \pm 0.13$ & $0.320 \pm 0.08$ & 5 & C29 [1], C30 [1], C31 [1], C32 [1], C33 [1] \\
\hline HAL & N 483' $19,9^{\prime \prime}$, E $24^{\circ} 57^{\prime} 47,2^{\prime \prime}$ & $0.9 \pm 0.16$ & $0.357 \pm 0.08$ & 4 & C34 [2], C35 [1], C36 [1], C37 [1] \\
\hline POU & N 483' $42,9^{\prime \prime}$, E $16^{\circ} 44^{\prime} 56,7^{\prime \prime}$ & $0.9 \pm 0.16$ & $0.160 \pm 0.04$ & 4 & C38 [1], C39 [2], C40 [1], C41 [1] \\
\hline
\end{tabular}

${ }^{a}$ Symbols for the populations were derived from the names of cities or towns situated nearest to a particular population (these symbols are used in Fig. 1). Localities in Poland: KRA - Krakow; DAL - Dale; CHO - Chotel; BOC - Bochotnica; GRO - Gródek; KOR - Korhynie; MIE - Mielnik; ROZ - Rożubowice; JAR - Jarosław; SZC - Szczepanowice; BIS - Biskupice; KAL - Góra Kalwaria; MOD - Modlin; WLO - Włocławek; GOG - Gogolin; GLO - Głogów; SAN - Sandomierz; DOB - Dobre; GRE - Grędziec; NIE - Nieszawa; PLU - Płutowo. Localities in Ukraine: ZLO - Złoczów; BRO - Brody; HAL - Halicz. Locality in Czech Republic: POU - Pouzdřany. Locality in Slovakia: BRA - Bratislava.

light of the ecology and past history of the species studied and compared with results of other analyses (Garrick et al., 2008). In this study the NPCA results were verified in this way.

\section{Demography and population genetics}

Populations of each species were grouped according to their geographical locations (Table 1). $F_{S T}$ indices (Wright, 1951) were calculated using ARLEQUIN 3.1 (Schneider et al., 2000). Populations of $P$. inustus were divided into 6 clusters: Małopolska Uplands [KRA, DAL, CHO, SAN], eastern Poland [BOC, GRO, KOR, MIE], Carpathian Foothills [BIS, SZC, JAR, ROZ], Vistula valley [KAL, MOD, WLO], Oder valley [GOG, GLO], and western Ukraine [ZLO, HAL]. Populations of
C. leucogrammus were divided into 5 clusters: Małopolska Uplands [DAL, CHO, DOB, SAN], Pomerania [GRE], MoraviaSlovakia [BRA, POU], Vistula valley [PLU, NIE], and western Ukraine [ZLO, BRO, HAL] with eastern Poland [GRO]. A Mantel test (Mantel, 1967) was performed in ARLEQUIN 3.1 to check if the genetic structure of the populations fits an isolation by distance model (IBD) (Slatkin, 1993), using pairwise $F_{S T}$ values and straight-line geographic distances in kilometers. To test for the presence of contemporary or historical barriers between populations, a spatial analysis of molecular variance was conducted using the program SAMOVA (Dupanloup et al., 2002). A mismatch distribution (MD) (Rogers \& Harpending, 1992) and Fu's test $\left(F_{S}\right)(\mathrm{Fu}, 1997)$ were calculated in ARLE- 


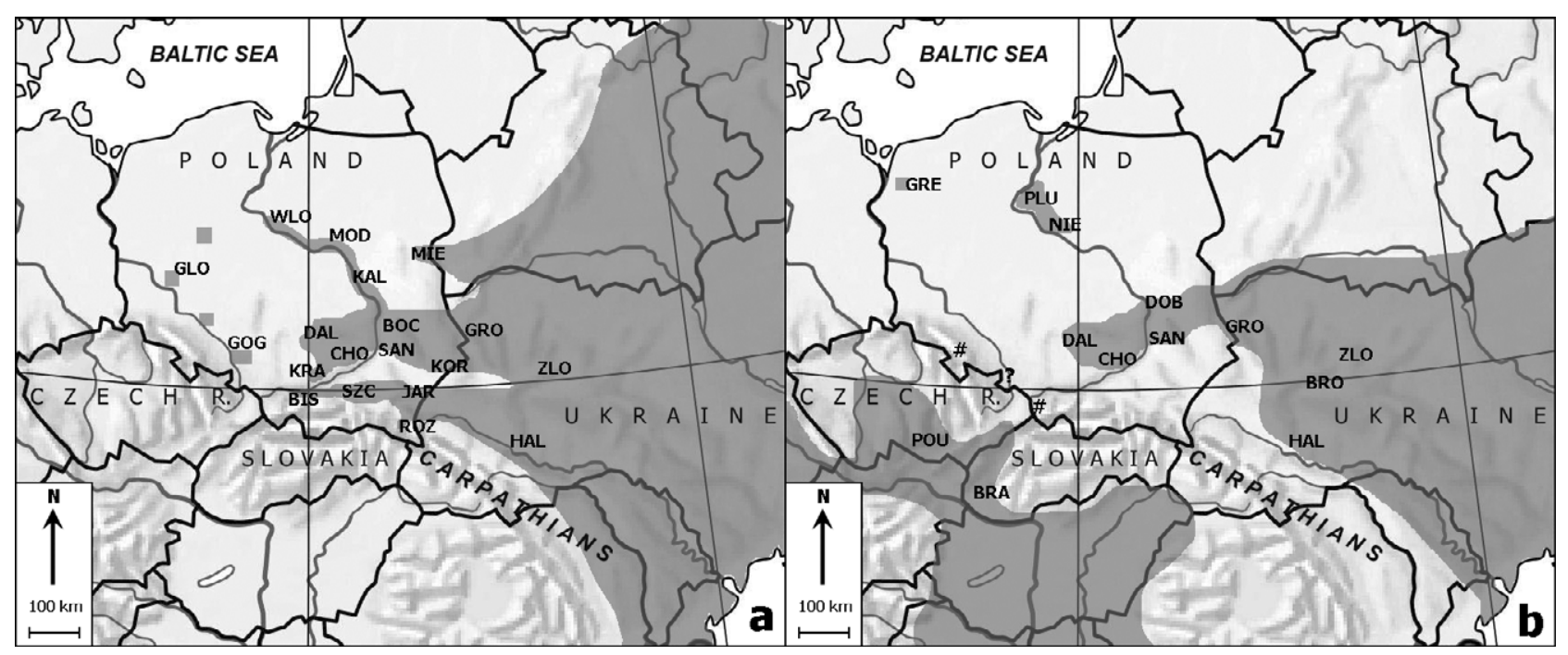

Fig. 1. Maps of central Europe with distribution ranges of the weevils studied (dark grey area): P. inustus (a) and C. leucogrammus (b). Symbols for populations (sampling sites), such as KRA, DAL, etc., were derived from the names of cities or towns situated nearest to that population (see Table 1 for full names). \# - extinct; ? - probably extinct.

QUIN 3.1 in order to examine the demographic history, and specifically, test for historical (temporal) expansions of populations of both species. The probable time of expansion (how long ago the expansion occurred) was estimated by the parameter $\tau=2 u t$ (where $u=m_{\mathrm{T}} \mu ; m_{T}$ - length of analyzed sequence, $\mu$ - mutation rate; $t$ - number of generations since expansion) obtained from the MD. Mutation rate was the same as that assumed for the divergence time (1.5-2.0\% per million years) and $t$ as 1 generation / year. The level of migration between populations was estimated using the frequency of private haplotypes (Np) (Slatkin, 1985) and $F_{S T}$ indices (Wright, 1951), for which values below 0.33 (for mtDNA) indicate high gene flow (Cockerham \& Weir, 1993).

\section{RESULTS}

\section{Genetic diversity of populations}

There were 15 haplotypes in the 92 individuals of $P$. inustus, 6 of which were found only in single specimens (Table 1). The 1643 bp long sequences showed 13 polymorphic sites. Codon position polymorphism was as follows: $5(0.9 \%), 2(0.3 \%)$, and $7(1.3 \%)$ for $1^{\text {st }}, 2^{\text {nd }}$, and $3^{\text {rd }}$ codon positions, respectively. Mean haplotype diversity (h) was $0.795 \pm 0.028$ and mean nucleotide diversity $(\pi)$ was $0.071 \% \pm 0.005$ (Table 1 ). Ten populations were monomorphic (Table 1). The number of private haplotypes was 0 in 8 populations and 1 in 11 populations (Table 1). Two haplotypes were particularly widespread: $\mathrm{P} 1$ found in 32 individuals and P7 found in 25 individuals (Table 1).

Genetic diversity of $C$. leucogrammus populations was much greater. There were 41 haplotypes in the 65 individuals of C. leucogrammus of which 29 were found only once (Table 1). The 1626 bp long sequences showed 44 polymorphic sites. Codon position polymorphism was as follows: $9(1.7 \%), 3(0.6 \%)$, and $27(5.0 \%)$ for $1^{\text {st }}, 2^{\text {nd }}$, and $3^{\text {rd }}$ codon positions, respectively. Mean haplotype diversity $(h)$ was $0.981 \pm 0.006$ and mean nucleotide diversity $(\pi)$ was $0.564 \% \pm 0.017 \%$ (Table 1 ). No population was monomorphic (Table 1). The number of private haplo- types varied from 1 in 2 populations to 5 in 2 populations and except for one pair of populations (DAL and DOB from Małopolska Uplands), no haplotypes were shared between populations (Table 1).

\section{Phylogeography}

For each species, the topologies of the gene trees (Figs 2a, 3a) and haplotype networks (Fig. 2b, 3b) were similar. In $P$. inustus, haplotypes were grouped into 3 clades (Fig. $2 \mathrm{a}, \mathrm{b})$. These clades and haplotypes were separated from each other only by single mutations. Clade 1-1 was limited to 9 individuals from the Małopolska Uplands. Clade 1-2 was broadly distributed - 31 individuals from this clade were found in the eastern (Roztocze Uplands, cen-
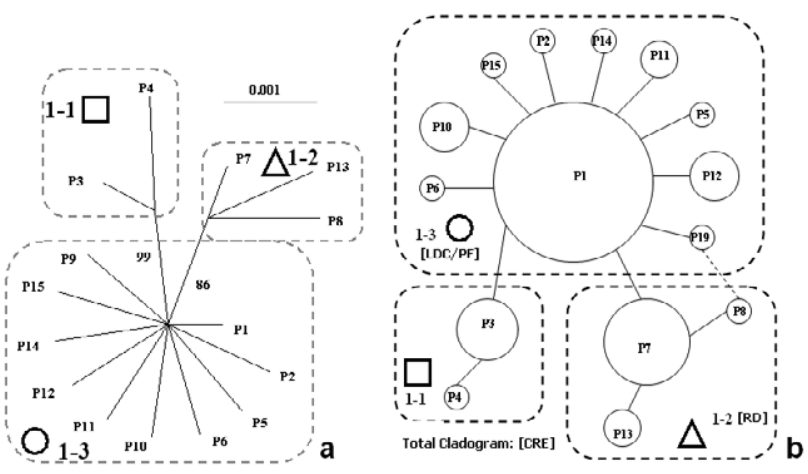

Fig. 2. Unrooted phylogenetic tree based on Bayesian Inference (a) and network of Statistical Parsimony (b) of 15 mtDNA haplotypes of $P$. inustus. Posterior probabilities are indicated on the tree and nested clades are shown in the network. Dashed lines enclose clades (with probabilities <0.05) inferred by NCPA: LDC/PF - Long distance colonization and/or past fragmentation, $\mathrm{RD}$ - Restricted long distance dispersal of nonsexual species, CRE - Contiguous range expansion. Dotted line between P9 and P8 indicates a second possible connection between these two haplotypes in the network. Each 1-step clade is marked either by a square, circle or triangle, which correspond to the symbols in Fig. 4a. 


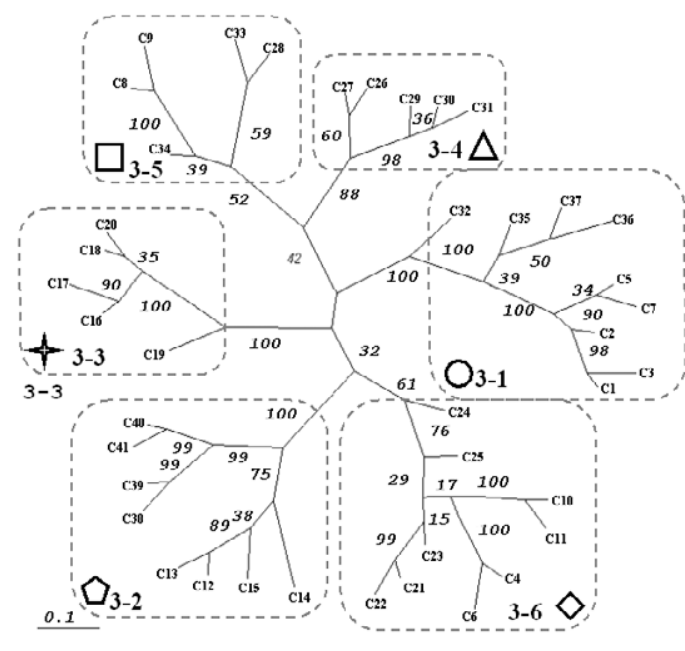

a

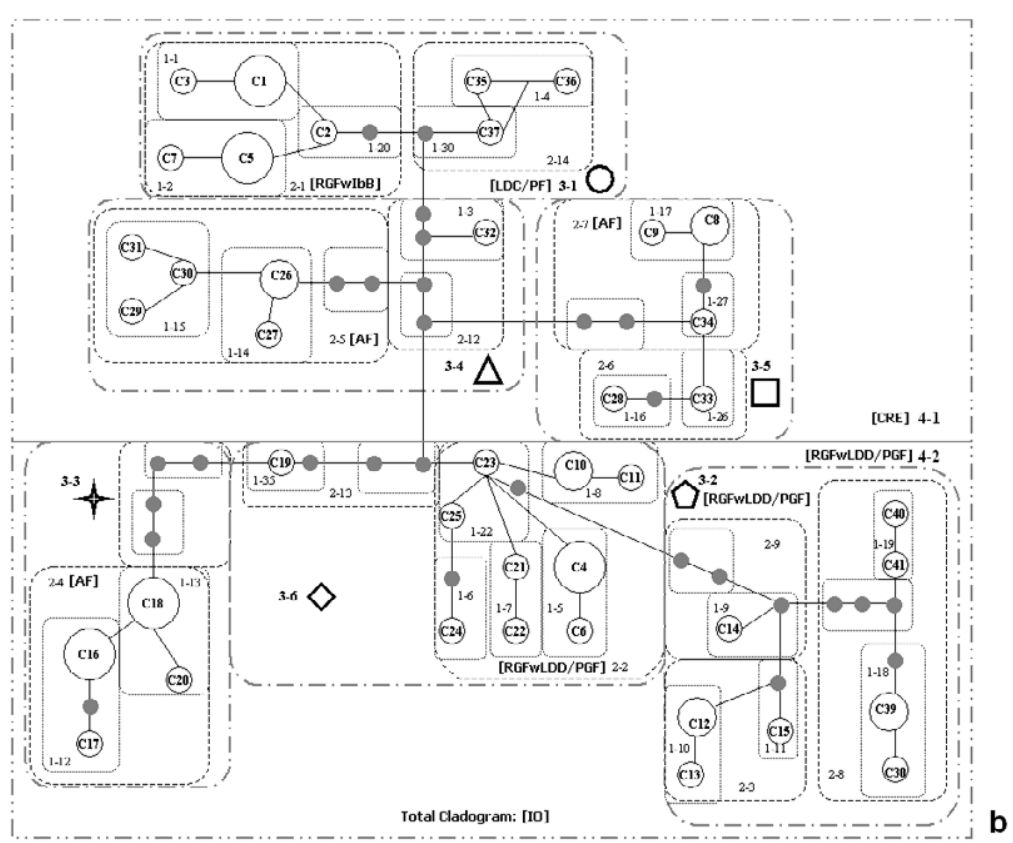

Fig. 3. Unrooted phylogenetic tree based on Bayesian Inference (a) and network Statistical Parsimony (b) of 41 mtDNA haplotypes of $C$. leucogrammus. Posterior probabilities are indicated on the tree and nested clades are shown in the network. Dashed lines enclose clades (with probabilities < 0.05) inferred by NCPA: LDC/PF - Long distance colonization and/or past fragmentation, CRE - Contiguous range expansion, RGFwIbD - Restricted gene flow due to isolation by distance, RGFwLDD - Restricted gene flow/dispersal but with some long-distance dispersal over areas not occupied by the species, PGF - Past gene flow followed by extinction of intermediate populations, AF - Allopatric fragmentation, IO - Inconclusive outcome. Each 3-step clade is marked either by a square, circle, triangle, pentagon, star or diamond, which correspond to symbols in Fig. 4b.

tral Vistula Valley and Bug Valley) and the western parts of Poland (lower Vistula Valley and Oder Valley). The most numerous clade, 1-3 (52 individuals), was represented by samples from western Ukraine and eastern Poland, the Carpathian Foothills and the Vistula Valley (Fig. 4a). Individuals of $P$. inustus with mtDNA haplotypes from 2 clades (1-3 and 1-2 or 1-1 and 1-3) were found only in populations along the central part of the basin of the Vistula river.

Haplotypes found in C. leucogrammus were grouped into 6 clades (3-step clades in NCPA analyses) (Fig. 3a, b). Clade 3-1 did not have a compact range - 10 individuals with haplotypes from this clade were found in southern Poland (CHO, DOB, DAL) and 3 individuals from one population from western Ukraine (HAL). Hap-

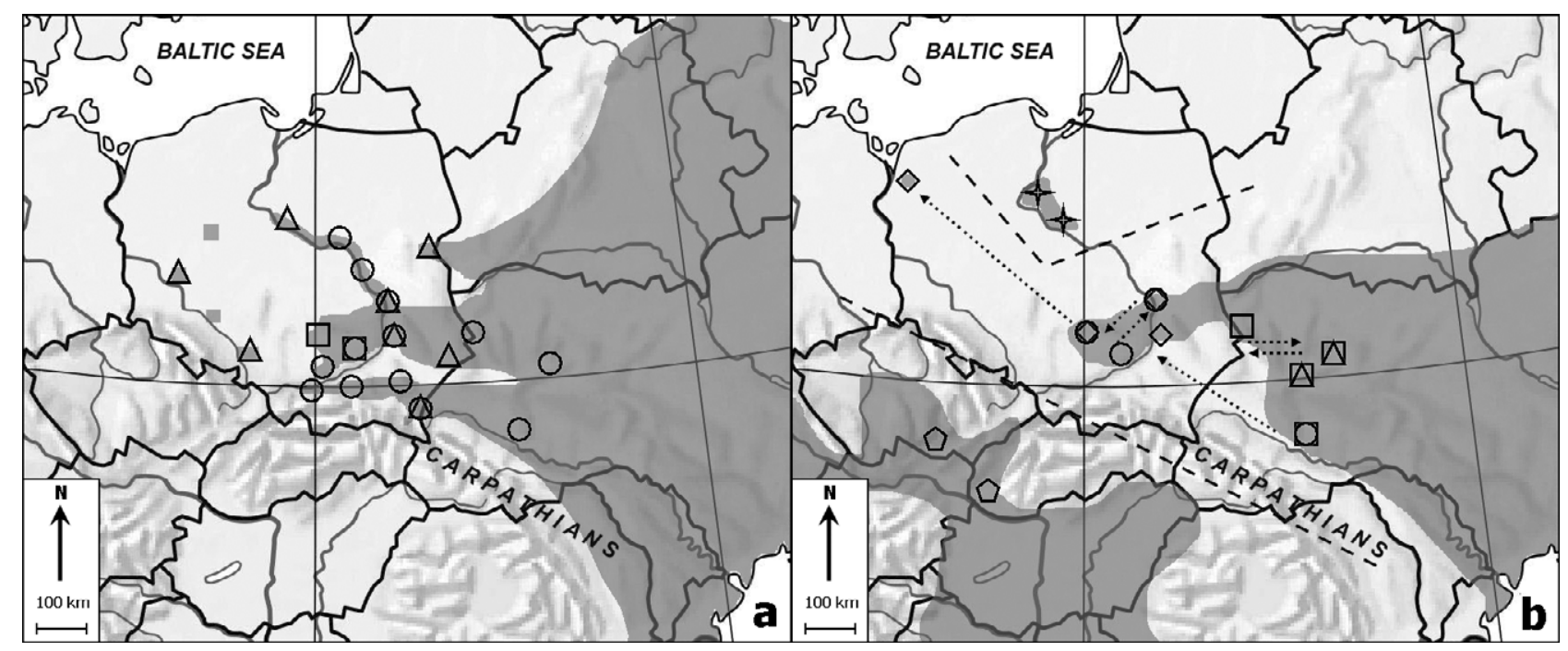

Fig. 4. Geographic distribution of mtDNA clades in central Europe, as indicated by haplotype trees (Fig. 2a, b) and networks (Fig. $3 \mathrm{a}, \mathrm{b}$ ), in populations of $P$. inustus (a) and C. leucogrammus (b). The symbols of clades (square, circle, triangle, pentagon, star or diamond) are the same as in Figs 2 and 3, respectively; dark grey area indicate species distribution range, broken lines - boundaries between genetically distinct groups and dotted arrows - possible migration routes of C. leucogrammus. 

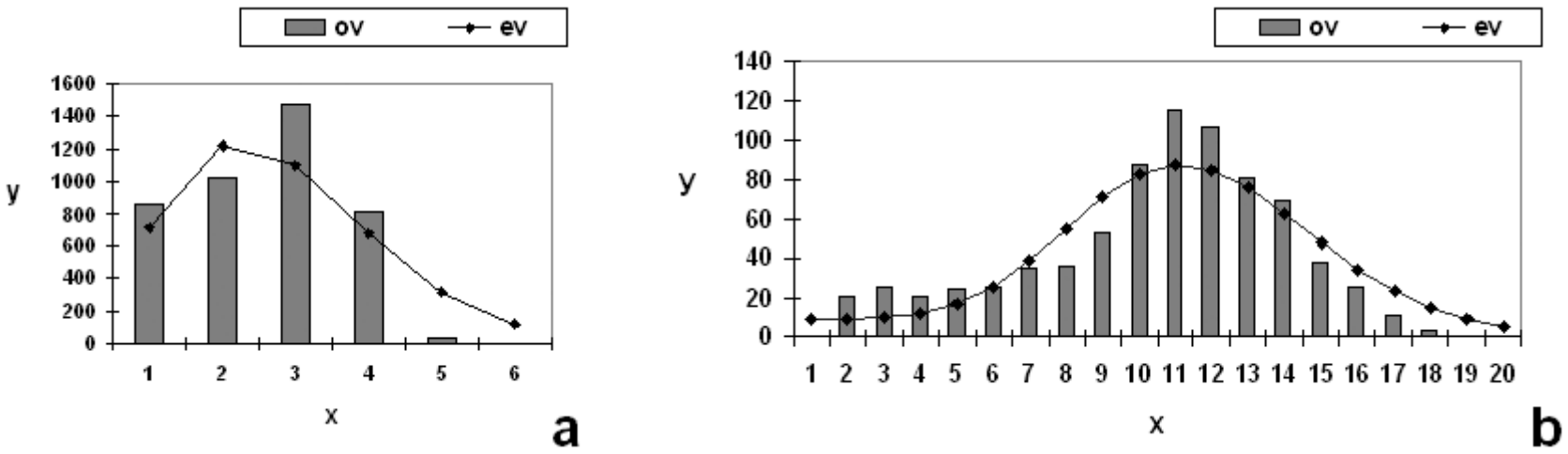

Fig. 5. Histograms of mismatch distributions (MD) for P. inustus (a) and C. leucogrammus (b). $\mathrm{x}$ axis - differences between pairs of haplotypes, y axis - frequency of differences, ov - observed values, ev - expected values.

lotypes from clade 3-2 were found only in Moravia (POU) and southern Slovakia (BRA) (in both 5 individuals). Ten individuals from the lower Vistula valley (NIE, PLU) were grouped in clade 3-3. Clade 3-4 consisted of 8 individuals from western Ukraine (ZLO, BRO). Haplotypes from clade 3-5 were found in all populations from western Ukraine (4 individuals) and eastern Poland (GRO) (5 individuals). Clade 3-6 grouped haplotypes from southern Poland (CHO, SAN, DOB) $\quad(10$ individuals) and surprisingly from Pomerania (GRE) in northwestern Poland (5 individuals) (Fig. 4b). The only differences between the tree and the network were the positions of two intermediate haplotypes: C19 (situated in clade 3-3 in the tree and clade 3-6 in the network) and C32 (situated in clade 3-1 in the tree and clade 3-4 in the network). The most probable explanations of the present geographic distribution of haplotypes and clades of both species obtained by NCPA analyses are presented in Figs $2 b$ and $3 b$.

\section{Divergence and expansion times}

Because of the little divergence between clades of $P$. inustus, their divergence times could not be calculated. The MD results $(\tau=1.324 ; 95 \%$ confidence intervals $0.787-2.725)$ for this species showed that the expansion of the populations studied occurred between 55000 and 12000 years ago (Fig. 5a). The demographic expansion was also confirmed by Fu's test $\left(F_{S}=-6.87629, P=\right.$ 0.006).

The mean pairwise distance between clades of C. leucogrammus is between 0.3 and $0.6 \%$, yielding a divergence time of between 380000 and 150000 years ago. MD results showed that the expansion of central European populations of $C$. leucogrammus occurred between 280 000 and 110000 years ago $(\tau=9.823,95 \%$ confidence intervals 7.129-13.631) (Fig. 5b). A significant result of Fu's test $\left(F_{S}=-20.00875, P<0.001\right)$ also confirms the demographic expansion.

\section{Isolation and migration}

For most pairs of groups of $P$. inustus populations $F_{S T}$ indices are lower than 0.33 , which suggest moderate genetic differences between them (Table 2). The genetic $\left(F_{S T}\right)$ and geographic $(\mathrm{km})$ distances between populations of this weevil did not appear to be correlated (the result of Mantel test was not significant: $r=0.0355, P=0.4$ ) (Fig. $6 a)$. According to the SAMOVA, the largest differences between groups of populations $(66.2 \%)$ occur when populations are divided into 5 clusters: Małopolska Uplands (CHO, DAL) (1), vicinity of Krakow (BIS) (2), vicinity of Warsaw (MOD) (3), eastern Poland (SAN, KOR, MIE) (4) and all other populations (5). In this division of the populations, $11 \%$ of the genetic differences are ascribed among populations within groups and $22.8 \%$ within populations. This division does not delineate clear

TABLE 2. The $F_{S T}$ indices (below diagonal) and their statistical significance (above diagonal) for pairs of populations of $P$. inustus and C. lecucogrammus. Grouping of populations into clusters is described in Material and methods (* - values of $F_{S T}$ that are significant at $P<0.05$ ).

\begin{tabular}{|c|c|c|c|c|c|c|c|c|c|c|c|c|}
\hline \multirow{2}{*}{$\begin{array}{c}\text { Cluster of } \\
\text { populations }\end{array}$} & \multicolumn{6}{|c|}{ P. inustus } & \multirow{2}{*}{$\begin{array}{c}\text { Cluster of } \\
\text { populations }\end{array}$} & \multicolumn{5}{|c|}{ C. lecucogrammus } \\
\hline & 1 & 2 & 3 & 4 & 5 & 6 & & 1 & 2 & 3 & 4 & 5 \\
\hline 1 & 0.00 & $*$ & $*$ & $*$ & $*$ & * & 1 & 0.00 & $*$ & $*$ & $*$ & * \\
\hline 2 & 0.18 & 0.00 & & & $*$ & $*$ & 2 & 0.40 & 0.00 & $*$ & $*$ & $*$ \\
\hline 3 & 0.24 & 0.33 & 0.00 & $*$ & $*$ & * & 3 & 0.46 & 0.68 & 0.00 & $*$ & $*$ \\
\hline 4 & 0.24 & 0.32 & 0.21 & 0.00 & $*$ & * & 4 & 0.60 & 0.86 & 0.68 & 0.00 & $*$ \\
\hline 5 & 0.19 & 0.31 & 0.11 & 0.17 & 0.00 & $*$ & 5 & 0.29 & 0.49 & 0.44 & 0.51 & 0.00 \\
\hline 6 & 0.18 & 0.28 & 0.17 & 0.17 & 0.18 & 0.00 & & & & & & \\
\hline
\end{tabular}

1- Malopolska Uplands; 2 - eastern Poland; 3 - Carpathian Foothills; 1 - Malopolska Uplands; 2 - Pomerania; 3 - Moravia-Slo4 - Vistula Valley; 5 - Oder Valley; 6 - western Ukraine. vakia; 4 - Vistula Valley; 5 - western Ukraine. 

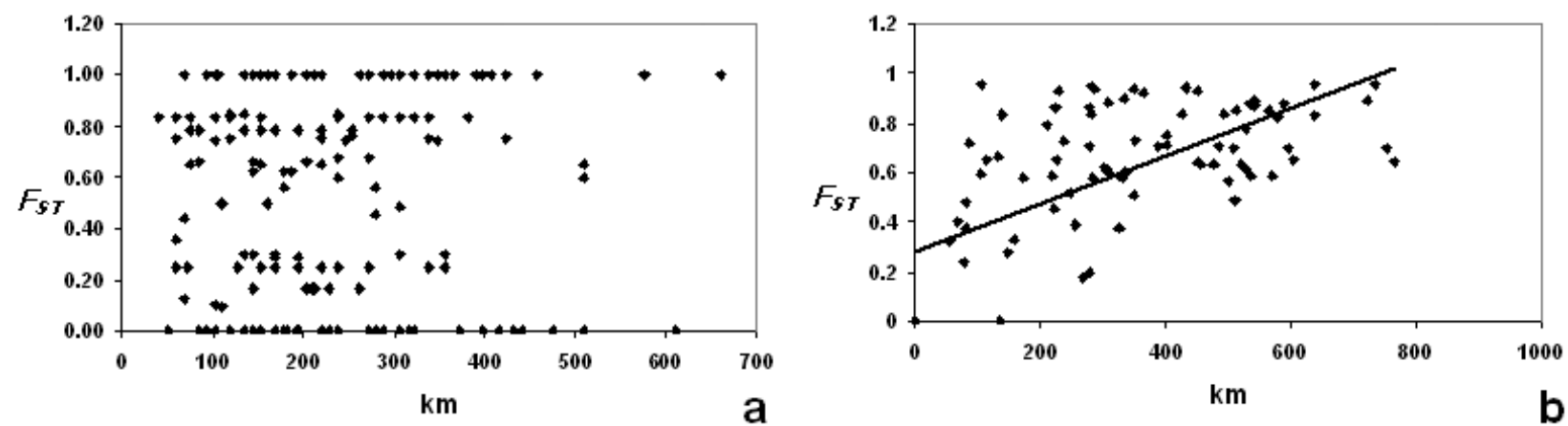

Fig. 6. The relationship between genetic $\left(F_{S T}\right)$ and geographic distance $(\mathrm{km})$ for populations of $P$. inustus (a) and $C$. leucogrammus (b) (Mantel tests).

borders between groups of populations because four of them are located inside the range of cluster which include most of populations.

$F_{S T}$ indices for most pairs of regional groups of $C$. leucogrammus populations are larger than 0.33 indicating that these groups are isolated from each other (Table 2). An $F_{S T}$ value of 0.29 indicates possible migrations only for populations from the Małopolska Uplands and western Ukraine-eastern Poland. Populations of C. leucogrammus fit the IBD model (significant result of Mantel test: $r=0.421, P=0.003$ ), i.e. generally populations more genetically distinct are more distant in space, however, this correlation is rather weak (Fig. 6b). According to the SAMOVA, the largest differences between groups of populations (but only $34.5 \%$ ) occur when populations are divided into three clusters: western Ukraine with southeastern Poland and one population from Pomerania (1), Moravia with Slovakia (2) and lower Vistula valley (3). Such a division is partially concordant with gaps in the present range of the species. However, the high percentage of genetic differences among populations within groups $(41.0 \%)$ and within populations $(24.5 \%)$ showed that almost all populations are significantly different from one another.

\section{DISCUSSION}

\section{Origin and phylogeography of xerothermic weevils in central Europe}

The low genetic differentiation of $P$. inustus populations in central Europe suggests they are of recent origin. As bisexual populations of this weevil are known only from Black Sea-Caspian Sea area (Korotyaev, 1996) it is most likely that its parthenogenetic form arose there and afterwards spread into eastern and central Europe. The origin of parthenogenesis in this species is not known but preliminary studies (Kajtoch et al., in press) suggest that it is a result of hybridization. Expansion of the parthenogenetic form of $P$. inustus took place during the Vistulian (Weichselian) glaciation (55000 - 12000 years ago) when steppe-like habitats were more common. Dispersal and colonization of new areas are ongoing because new populations of this species were found recently in areas where they had not been found earlier despite intensive investigations (Mazur, 1994). The geographic distribution of the mainly parapatric clades of $P$. inustus suggests at least two episodes of expansion of these weevils in central Europe. The disjunctive range of clade 1-2 (which occupied eastern Poland and isolated localities in western Poland) probably resulted from individuals of clade 1-3 spreading from the western Ukraine along the Carpathian foothills and through the Lubelska Uplands to the Vistula valley. Such a conclusion is also supported by NCPA results, which explain the present distribution of clades 1-2 and 1-3 as dispersal restricted by distance and long distance colonization and/or past fragmentation. Haplotypes belonging to two clades were found in populations along the central part of the basin of the Vistula River. Such population admixture may have originated as a result of migration of specimens from different localities. Haplotypes from clade 1-1 (found only at two localities in the Małopolska Uplands) probably originated as a result of a founder event and limited spread.

The much greater genetic diversity of individuals and populations of $C$. leucogrammus and mixed distribution of its clades (allopatric and sympatric) is probably the result of the long-term existence of these weevils in central Europe. Estimated divergence times between main clades (380 $000-150000$ years ago) and expansion time (280 $000-110000$ years ago) are nested in the second part of the Pleistocene, which accords with the present knowledge of the distribution of steppe-like habitats and species in central Europe. Even if these weevils (or other steppe species) existed in the area to the north of the Carpathian-Sudeten Mts before 430000 BP, they could not have survived the most extensive Sanian (Cromenian) glaciation. During the second part of the Pleistocene insects in temperate and boreal areas in Eurasia and North America diverged (Stauffer et al., 1999; Ritzerow et al., 2004; Laffin et al., 2005; Grapputo et al., 2005; Maroja et al., 2007). Present spatial distribution of C. leucogrammus clades is a result of several past events. Distribution of haplotypes from clade 4-1 is probably a result of contiguous range expansion. This is not surprising because that clade was found in populations from western Ukraine and south-eastern Poland - the western part of the main, continuous range of $C$. leucogrammus. On the other hand geographic distributions of clades 2-4, 2-5, 2-7, and 3-1 are explained by allopatric divergence or long distance colonization and past fragmentation. These 
clades are represented by specimens from isolated groups of populations from the lower Vistula Valley or from separate populations from western Ukraine and eastern Poland. Geographic localization of specimens belonging to the second main clade (4-2) is probably a result of restricted gene flow with isolation by distance, longdistance dispersal over areas not occupied by the species or past gene flow followed by extinction of intermediate populations. Haplotypes belonging to the 4-2 clade are found in three groups of populations, clearly isolated at present: eastern (Polish-Ukrainian), southern (MoravianSlovakian), and northern (from lower Vistula Valley). Past gene flow followed by extinction of intermediate populations is also the best explanation for the geographic distribution of clade 3-6. That clade was found not only in some populations from southern Poland but also in a population from Pomerania (GRE). It is isolated from other localities by a wide break in the species range of about $300 \mathrm{~km}$. The hypothesis of extinction of some populations is also supported by the 33 haplotypes identified in the network but not present in the collected material. A similar allopatric and sympatric distribution of clades is observed in many insects from the temperate zone such as the bark beetle, Dendroctonus rufipennis, leaf beetle, Gonioctena pallida, and ground beetle, Carabus solieri (Mardulyn, 2001; Garnier et al., 2004; Maroja et al., 2007), also the xerothermic snail Candidula unifasciata (Pfenninger \& Posada, 2002; Pfenninger et al., 2003) and xerothermic butterfly Clouded Apollo Parnassius mnemosyne (Gratton et al., 2008). These species each consist of few main clades, which survived the Pleistocene in different refuges in which they diverged from one another. Afterwards these phylogenetic lineages expanded and now occur sympatrically at some localities.

\section{Isolation and migration}

Our study revealed that five genetically distinct groups of $P$. inustus populations are not separated geographically. One group is particularly widespread and the rest are localized inside the range of the main cluster. Such population division may be the result of a recent colonization of central Europe or migration between contemporary localities. In this case both explanations are probably correct because these beetles arrived in central Europe at the end of the last ice-age and have been spreading ever since. Such a scenario is confirmed by the NCPA, which inferred a continuous range expansion for all clades. Values of $F_{S T}$ below 0.33 for most pairs of geographic groups of populations, the low number of private haplotypes $(\mathrm{Np})$ in populations and lack of correlation between geographic and genetic distances also confirm present migration and/or recent colonization. Despite being flightless, individuals of $P$. inustus are able to move and survive outside of xerothermic habitats (Mazur, 2001). Parthenogenesis may facilitate expansion because only a single female or group of female clones is needed for the foundation of a new population. Lack of genetic differences in mtDNA in several populations, in which only one haplotype was found, is probably the result of a founder effect. Human-mediated dispersal may also pro- mote the dispersal of $P$. inustus (Mazur, 1994). A similar lack of genetic differences between populations was found in many highly mobile (often flying) species of weevils and bark beetles, which inhabit the coniferous forests of Eurasia (Stauffer et al., 1999; Faccoli et al., 2005; Conord et al., 2006; Lakatos et al., 2007). These species are tree pests and spread only a few thousand years ago after climate warming. The low genetic differences among populations of these beetles may also be a result of human-aided dispersal.

Three groups of $C$. leucogrammus populations are separated by wide breaks in the species range - areas which are not suitable for this species at present (farmland and forested mountains) but which might had been occupied in the past. On the other hand, the distribution of clades in some populations from southern and eastern Poland together with western Ukraine are the result of long distance colonization and/or past fragmentation, restricted gene flow with isolation by distance and contiguous range expansion. Evidence for gene flow between populations in southern Poland, eastern Poland and western Ukraine is also supported by $F_{S T}$ values, which are lower than 0.33 only between these groups of populations, and by the presence of similar (closely related) haplotypes in distant populations from the Małopolska Uplands (DAL, CHO, DOB) and western Ukraine (HAL), eastern Poland (GRO) and western Ukraine (BRO, ZLO, $\mathrm{HAL}$ ), and also between regional groups of populations in the Małopolska Uplands (DAL, CHO, DOB, SAN) and western Ukraine (HAL, ZLO, BRO). These data and the presence of a high frequency of private haplotypes (Np) in most of the populations support migration in the past rather than the present. Only in one case, in populations DAL and DOB from the Małopolska Uplands were the same haplotypes detected, which is strong evidence for recent gene flow. The remaining populations, especially from distant localities, are now isolated. Such a scenario is also congruent with the result of the Mantel test, which indicate a weak but significant correlation between the geographic and genetic distances of populations.

\section{General conclusions}

According to Coope (1994), insects may react to changes in climate and environment in at least three ways. They may evolve (produce new forms better adapted to changing conditions), move (changes in distribution, populations in the northern part of the range may go extinct but survive in southern refuges) or become extinct (applies mostly to species which inhabit isolated and small areas and are unable to migrate). The genetic diversity of the weevils studied showed that xerothermic species exhibit at least two strategies for surviving climatic oscillations. Polydrusus inustus represents a group of asexual forms and/or highly mobile insects with a relatively short history in central Europe. This insect survived glaciations in southern refuges and spread to Eurasian steppe-xerothermic habitats during warmer periods and is a good example of Coope's second strategy. On the other hand, Centricnemus leucogrammus is an example of a relic element and is probably representative of other 
bisexual species with poor dispersal abilities, which have existed in central Europe since the end of the most extensive Sanian glaciation (after 430000 years ago). These species probably consist of many phylogenetic lineages, which diverged during interglaciations in separate warmstage refuges (Bhagwat \& Willis, 2008), such as steppelike habitats in western Ukraine (Wolyn and Podole Uplands), southern Poland (Małopolska Uplands), the Pannonian Basin and maybe also further to the north. They expanded during the following glaciations resulting in a partially overlapping distribution of clades. C. leucogrammus fits Coope's first strategy but its clades have not had enough time to evolve into distinct taxonomic units. However, it is probable that such units exist somewhere within the wide range of this species. Further studies on different species of xerothermic insects should reveal whether the results of this study are general for all steppelike insect assemblages in Europe.

ACKNOWLEDGEMENTS. We would like to thank greatly people who helped us during the successive stages of this work: M. Holecová, B. Petryszak, S. Knutelski, M. Mazur, W. Rizun, D. Kubisz, and W. Babik. This work was supported by a grant (N304 085 31/3279) from the Polish Ministry of Higher Education and Science.

\section{REFERENCES}

Avise J.C. 2000: Phylogeography: The History and Formation of Species. Harvard University Press, Cambridge, Massachusetts, viii $+447 \mathrm{pp}$.

Barraclough T.G. \& Vogler A.P. 2002: Recent diversification rates in North American tiger beetles estimated from a dated mtDNA phylogenetic tree. Mol. Biol. Evol. 19: 1706-1716.

Beaumont M.A. \& Panchal M. 2008: On the validity of nested clade phylogeography analysis. Mol. Ecol. 17: 2563-2565.

Bereczki J., Pecsenye K., Peregovis L. \& Varga Z. 2005: Pattern of genetic differentiation in the Maculinea alcon species group (Lepidoptera, Lycaenidae) in Central Europe. Syst. Zool. Evol. Res. 43: 157-165.

Bhagwat S.A. \& WiLlis K.J. 2008: Species persistence in northerly glacial refugia of Europe: a matter of chance or biogeographical traits? J. Biogeogr. 35: 464-482.

CACCone A. \& SBordoni V. 2001: Molecular biogeography, evolutionary rates, and morphological adaptation to cave life: a case study using Bathysciinae beetles and sequence data from the mitochondrial COI gene. Evolution 55: 122-130.

Clement M., Posada D. \& Crandall K.A. 2000: TCS: a computer program to estimate gene genealogies. Mol. Ecol. 9: $1657-1659$

Cockerham C.C. \& Weir B.S. 1993: Estimation of gene flow from F-statistics. Evolution 47: 855-863.

Conord C., Lempérière G., Taberlet P. \& Després L. 2006: Genetic structure of the forest pest Hylobius abietis on conifer plantations at different spatial scales in Europe. Heredity 97: 46-55.

Coope G.R. 1994: The response of insect faunas to glacialinterglacial climatic fluctuations. Philosophical Trans. R. Soc. Lond. (B) 344: 19-26.

Dupanloup I., Schneider S. \& Excoffier L. 2002: A simulated annealing approach to define the genetic structure of populations. Mol. Ecol. 11: 2571-2581.

Emerson B.C., Paradis E. \& ThÉBaud C. 2001: Revealing the demographic histories of species using DNA sequences. Trends Ecol. Evol. 16: 707-716.
Faccoli M., Blażenec M. \& Schlyter F. 2005: Feeding response to host and non-host compounds by males and females of the spruce bark beetle Ips typographus in a tunnelling microassay. J. Chem. Ecol. 31: 745-759.

FARRELL B.D. 2001: Evolutionary assembly of the milkweed fauna: cytochrome oxidase I and the age of tetraopes beetles. Mol. Phylogen. Evol. 18: 467-478.

Farris J.S., Källersjö M., Kluge A.G. \& Bult C. 1995: Constructing a significance test for incongruence. Syst. Biol. 44: $570-572$.

Fu X.-Y. 1997: Statistical tests of neutrality of mutations against population growth, hitchhiking and background selection. Genetics 147: 915-925.

Garnier S., Alibert P., Audiot P., Prieur B. \& Rasplus J.-Y. 2004: Isolation by distance and sharp discontinuities in gene frequencies: implications for the phylogeography of an alpine insect species, Carabus solieri. Mol. Ecol. 13: 1883-1897.

Garrick R.C., Dyer R.J., Beheregaray L.B. \& Sunnucks P. 2008: Babies and bathwater: a comment on the premature obituary for nested clade phylogeographic analysis. Mol. Ecol. 17: 1401-1403.

Grapputo A., Boman S., Lindström L., Lyytinen A. \& Mappes J. 2005: The voyage of an invasive species across continents: genetic diversity of North American and European Colorado potato beetle populations. Mol. Ecol. 14: 4207-4219.

Gratton P., Konopiński M.K. \& SBordoni S.V. 2008: Pleistocene evolutionary history of the clouded Apollo (Parnassius mnemosyne): genetic signatures of climate cycles and a "time-dependent" mitochondrial substitution rate. Mol. Ecol. 17: 4248-4262.

Hall T.A. 1999: BioEdit: a user-friendly biological sequence alignment editor and analysis program for Windows 95/98/NT. Nucl. Acids Symp. Ser. (Lond.) 41: 95-98.

Hasegawa M., Kishino H. \& Yano T. 1985: Dating of the human-ape splitting by a molecular clock of mitochondrial DNA. J. Mol. Evol. 22: 160-174.

Hewitt G.M. 1999: Post-glacial re-colonization of European biota. Biol. J. Linn. Soc. 68: 87-112.

Huelsenbeck J.P. \& Ronquist F. 2001: MRBAYES: Bayesian inference of phylogeny. Bioinformatics 17: 754-755.

Juan C., Oromi P. \& Hewitt G.M. 1996: Phylogeny of the genus Hegeter (Tenebrionidae: Coleoptera) and its colonization of the Canary Islands deduced from cytochrome oxidase I mitochondrial DNA sequences. Heredity 77: 392-403.

Kajtoch Ł. \& Lachowska-Cierlik D. (in press). Genetic constitution of parthenogenetic form of Polydrusus inustus (Coleoptera: Curculionidae) - hints of hybrid origin and recombinations. Folia Biol. (Kraków).

Korotyaev B.A. 1996: Use of data on distribution of the bisexual and parthenogenetic forms of weevils for faunogenetic reconstructions (Coleoptera, Curculionidae). In: Verhandlungen des 14. Internationalen Symposiums fur Entomofaunistik in Mitteleuropa, SIEEC, in Munchen (04.-09.09.1994). Munchen, pp. 264-271.

Kowalski K. (ed.) 1989: Historia i Ewolucja Ladowej Fauny Polski. [History and evolution of the terrestrial fauna of Poland.] PAN, Ossolineum, Kraków, 278 pp. [in Polish, English abstr.].

Knowles L.L. \& MAdDison W.P. 2002: Statistical phylogeography. Mol. Ecol. 11: 2623-635.

LachowsKa D., RożeK M., Kajtoch L. \& Holecová M. 2006: Cytogenetic differences between Peritelus familiaris and Centricnemus leucogrammus (Coleoptera: Curculionidae: Entiminae: Peritelini). Eur. J. Entomol. 103: 687-690. 
Lachowska D., RożeK M. \& Holecová M. 2008: New data on the cytology of parthenogenetic weevils (Coleoptera, Curculionidae). Genetica 134: 235-242.

LafFin R.D., Dosdall L.M. \& Sperling F.A.H. 2005: Population structure of the cabbage seedpod weevil, Ceutorhynchus obstrictus (Marsham) (Coleoptera: Curculionidae): Origins of North American introductions. Environ. Entomol. 34: 504-510.

Lakatos F., Grodzki W., Zhang Q.-H. \& Stauffe C. 2007: Genetic comparison of Ips duplicatus (Sahlberg, 1836) (Coleoptera: Curculionidae, Scolytinae) populations from Europe and Asia. J. Forest Res. 12: 345-349.

LiAnA A. 1987: Orthoptera of xerothermic habitats in Poland and their origin. In Baccetti B. (ed.): Evolutionary Biology of Orthopteroid Insects. Ellis Horwood, Chichester, pp. 342-346.

Mantel N. 1967: The detection of disease clustering and a generalized regression approach. Cancer Res. 27: 209-220.

Mardulyn P. 2001: Phylogeography of the Vosges mountains populations of Gonioctena pallida (Coleoptera: Chrysomelidae): a nested clade analysis of mitochondrial DNA haplotypes. Mol. Ecol. 10: 1751-1763.

Maroja L.S., Bogdanowicz S.M., Wallin K.F., Raffa K.F. \& HARRISON R.G. 2007: Phylogeography of spruce beetles (Dendroctonus rufipennis Kirby) (Curculionidae: Scolytinae) in North America. Mol. Ecol. 16: 2560-2573.

Mazur M. 1994: Rozmieszczenie i migracje Polydrusus inustus Germar, 1824 (Coleoptera: Curculionidae). Pol. Pis. Entomol. 63: $113-132$.

MAzur M. 2001: Ryjkowce kserotermiczne Polski (Curculionoidea: Nemonychidae, Attelabidae, Apionidae, Curculionidae). Studium zoogeograficzne. Monografie Fauny Polski 22: $1-378$.

Nehring A. 1890: Ueber Tundren und Steppen der Jetzt -und Vorzeit. Dümmler, Berlin, viii $+257 \mathrm{pp}$.

NeI M. 1987: Molecular Evolutionary Genetics. Columbia University Press, New York, NY, $\mathrm{x}+512 \mathrm{pp}$.

PANChal M. 2007: The automation of nested clade phylogeographic analysis. Bioinformatics 23: 509-510.

Panchal M. \& Beaumont M.A. 2007: The automation and evaluation of nested clade phylogeographic analysis. Evolution 61: 1466-1480.

PetryszaK B. 1977: A karyological study of five bisexual species of weevils (Curculionidae, Coleoptera). Zool. Polon. 26: 475-482.

Petit R.J. \& Grivet D. 2002: Optimal randomization strategies when testing the existence of a phylogeographic structure. Genetics 161: 469-471.

Pfenninger M. \& Posada D. 2002: Phylogeographic history of the land snail Candidula unifasciata (Poiret, 1801) (Helicellinae, Stylommatophora): fragmentation, corridor migration and secondary contact. Evolution 56: 1776-1788.

Pfenninger M., Posada D. \& Frederic M. 2003: Evidence for survival of Pleistocene climatic changes in Northern refugia by the land snail Trochoidea geyeri (Soos, 1926) (Helicellinae, Stylommatophora). BMC Evol. Biol. 3: 8.

Posada D. \& Crandall K.A. 1998. Modeltest: testing the model of DNA substitution. Bioinformatics 14: 817-818.

Posada D., Crandall K.A. \& Templeton A.R. 2000: Geodis: a program for the cladistic nested analysis of the geographical distribution of genetic haplotypes. Mol. Ecol. 9: 487-488.

Ribera I., Hernando C. \& Aquilera P. 2001: Agapus alexandae sp.n. from Marocco, with a molecular phylogeny of the Western Mediterranean species of the A. gattutus group (Coleoptera: Dytiscidae). Insect Syst. Evol. 32: 253-262.
Ritzerow S., Konrad H. \& Stauffer C. 2004: Phylogeography of the Eurasian pine shoot beetle Tomicus piniperda L. (Coleoptera, Scolytidae). Eur. J. Entomol. 101: 13-19.

Rogers A.R. \& HaRPENDING H. 1992: Population growth makes waves in the distribution of pairwise genetic differences. Mol. Biol. Evol. 9: 552-569.

RoNQUist F. \& HUELSENBECK J.P. 2003: MRBAYES 3: Bayesian phylogenetic inference under mixed models. Bioinformatics 19: $1572-1574$

Rozas J., Sánchez-Delbarrio J.C., Messeguer X. \& Rozas R. 2003: DNASP, DNA polymorphism analyses by the coalescent and other methods. Bioinformatics 19: 2496-2497.

Schneider S., Roessli D. \& Excoffier L. 2000: ARLEQUIN: A Software for Population Genetics Data Analysis. University of Geneva, Geneva, Switzerland.

Simon C., Frati F., Bechenbach A., Crespi B., Liu H. \& Flock P. 1994: Evolution, weighting, and phylogenetic utility of mitochondrial gene sequence and compilation of conserved polymerase chain reaction primers. Ann. Entomol. Soc. Am. 87: 651-701.

SLAtKIn M. 1985: Rare alleles as indicators of gene flow. Evolution 39: 53-65.

SLATKIN M. 1993: Isolation by distance in equilibrium and nonequilibrium populations. Evolution 47: 264-279.

Stauffer C., Lakatos F. \& Hewitt G.M. 1999: Phylogeography and postglacial colonization routes of Ips typographus L. (Coleoptera, Scolytidae). Mol. Ecol. 8: 763-773.

Swofford D.L. 2002: PAUP*. Phylogenetic Analysis Using Parsimony (*and Other Methods). Sinauer Associates, Sunderland, MA.

Taberlet P., Fumagalli L., Wust-Saucy A.G. \& Cosson J.F. 1998: Comparative phylogeography and postglacial colonisation routes in Europe. Mol. Ecol. 7: 453-464.

Tarasov P.E., Volkova V.S., Webb III T., Guiot J., Andreev A.A., Bezusko L.G., Bezusko T.V., Bykova G.V., Dorofeyuk N.I., Kvavadze E.V., Osipova I.M., Panova N.K. \& SevastyANOV D.V. 2000: Last glacial maximum biomes reconstructed from pollen and plant macrofossil data from northern Eurasia. J. Biogeogr. 27: 609-620.

TEMPLETON A.R. 1998: Nested clade analysis of phylogeographic data: Testing hypotheses about gene flow and population history. Mol. Ecol. 7: 381-397.

TEMPLETON A.R. 2001: Using phylogeographic analyses of genetrees to test species status and processes. Mol. Ecol. 10: 779-791.

TEMPLETON A.R. 2004: Statistical phylogeography: methods of evaluating and minimizing inference errors. Mol. Ecol. 13: 789-809.

Templeton A.R., Crandall K.A. \& Sing C.F. 1992: A cladistic analysis of phenotypic associations with haplotypes inferred from restriction endonuclease mapping and DNA sequence data. III. Cladogram estimation. Genetics 132: 619-633.

Thompson J.D., Gibson T.J., Plewniak F., Jeanmougin F. \& HigGINS D.G. 1997: The ClustalX windows interface: flexible strategies for multiple sequence alignment aided by quality analysis tools. Nucl. Acids Res. 24: 4876-4882.

Varga Z. 2003: Biodiversity and Phylogeography. Acta Biol Debr. 24: 5-38.

Willis K.J. \& van Andel T.A. 2004: Trees or no trees? The environments of central and eastern Europe during the Last Glaciation. Quat. Sci. Rev. 23: 2369-2387.

Wright S. 1951: The genetic structure of populations. Ann. Eugen. 15: 323-354.

Received December 8, 2008; revised and accepted April 21, 2009 